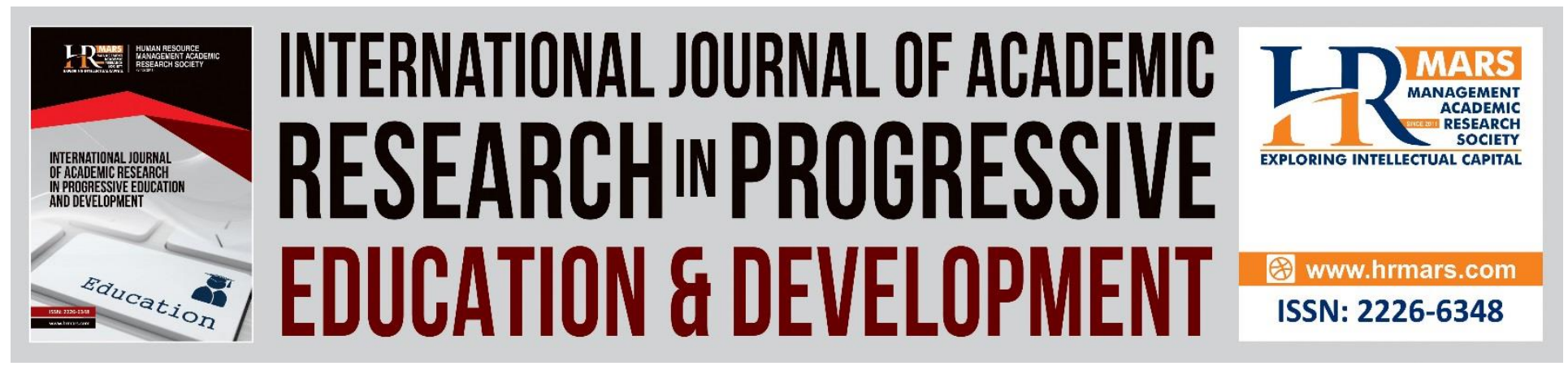

\title{
I Can't but I Can: Writing with the Left Hand in Primary School Classrooms
}

Rose Mugweni, Kudzai Chinyoka, Emily Ganga

To Link this Article: http://dx.doi.org/10.6007/IJARPED/v7-i4/5331

DOI: $10.6007 /$ IJARPED/v7-i4/5331

Received: 13 Nov 2018, Revised: 21 Dec 2018, Accepted: 06 Jan 2019

Published Online: 09 Jan 2019

In-Text Citation: (Mugweni, Chinyoka, \& Chinyoka, 2018)

To Cite this Article: Mugweni, R., Chinyoka, K., \& Chinyoka, K. (2018). I Can't but I Can: Writing with the Left Hand in Primary School Classrooms. International Journal of Academic Research in Progressive Education and Development, 7(4), 376-386.

Copyright: @ 2018 The Author(s)

Published by Human Resource Management Academic Research Society (www.hrmars.com)

This article is published under the Creative Commons Attribution (CC BY 4.0) license. Anyone may reproduce, distribute, translate and create derivative works of this article (for both commercial and non-commercial purposes), subject to full attribution to the original publication and authors. The full terms of this license may be seen

at: http://creativecommons.org/licences/by/4.0/legalcode

Vol. 7, No. 4, 2018, Pg. 376 - 386

http://hrmars.com/index.php/pages/detail/IJARPED

JOURNAL HOMEPAGE

Full Terms \& Conditions of access and use can be found at http://hrmars.com/index.php/pages/detail/publication-ethics 


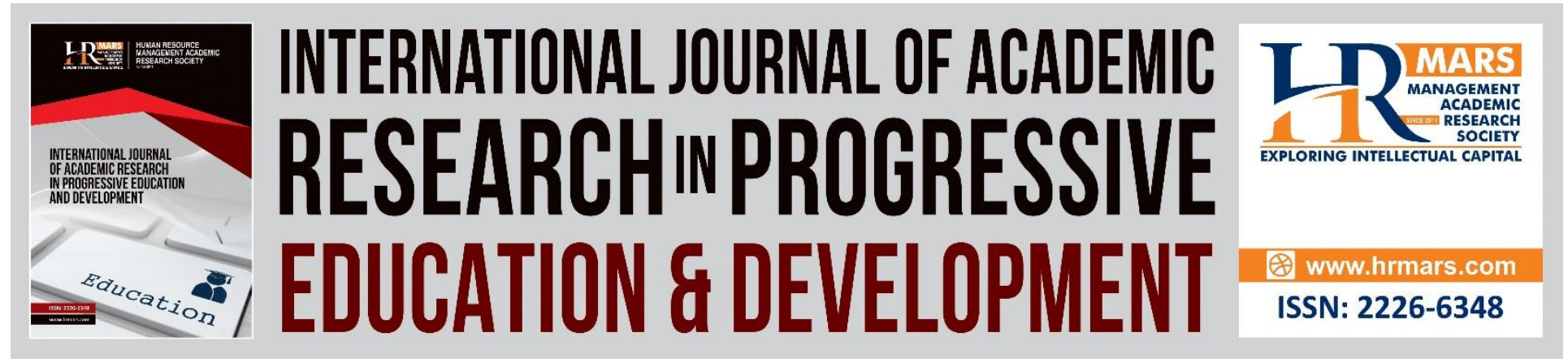

\title{
I Can't but I Can: Writing with the Left Hand in Primary School Classrooms
}

\author{
Rose Mugweni, Kudzai Chinyoka, Emily Ganga \\ Great Zimbabwe University, School of Education and Culture \\ Email: ro.mugweni@gmail.com,rmugweni@gzu.ac.zw
}

\begin{abstract}
Left-handed children from infancy right through their primary school days struggle to overcome the annoyance and frustration of living in a right-handed world. Resources and ideas specifically give best techniques to right-handed learners across the school curriculum, thereby marginalising left-handers. It is evident that children who are left-handed can learn new skills efficiently without awkwardness or frustration, to achieve their potential. This study aimed to (1) explore the experiences of left-handed learners in primary schools (2) Establish strategies teachers use to teach young children who are left-handed. (3) Document perceptions on how teacher-learner interactions affect left-handed children's learning and development. The Person-Environment Fit (PEF) Theoretical framework guided the study. A fundamental premise of PEF theory is that stress arises from a misfit between the person and environment.

A qualitative phenomenological case study was employed. The sample comprised of 40 participants. Twenty (20) teachers and twenty (20) learners were purposively selected from five (5) primary schools in Masvingo urban. Taking note of the learner's own voices was imperative in determining how they experienced writing with the left-hand in dominant right-handed classrooms. Data were collected through focus group discussions, individual interviews and observations. Tesch's open coding qualitative data analysis tool was used to analyse data.

Results show that left-handed learners had varied experiences ranging from sad emotions due to perceptions of marginalisation and negative labels; to happy emotions of success and positive self-efficacy. Techniques like exploring with both hands, hand dominance verbalisation, use of 'tripod' grasp, writing paper and model placement, right hand as 'helper hand' and use of ICT technologies were employed in the classrooms. Overall interactions negatively and positively affected children's learning and development. Among others, it was recommended that there was need for teachers, learners and parents to collaborate in order to alleviate challenges experienced by left-handers in primary school classrooms for positive development.
\end{abstract}

Keywords: Left-Handed, Person Environment Fit Theory, Learners, Primary School, Teacher, Infant School 


\section{Introduction}

Experience shows that usually young children clearly show writing hand dominance around six years of age, when they are in Grade one. At a younger age during ECD A and B within the Primary School, a child may use both hands. During this tender age adults should not try to force a child to write with the right hand. Literature (Vazi et. al, 2013; Luff, 2014) shows that if a child tends to be left-handed, forcing him or her to use the right hand can be harmful. In the primary school left-handed children who are not properly trained tend to develop bad writing habits and experience challenges. Such children may struggle and write slowly. This put the left-handers at a disadvantage when writing timed exercises and tests.

In the global village, $10 \%$ of the population are left-handed people (Luff, 2014). Unless a person is part of the population it is difficult to understand the differences between writing left-handed and right-handed. It is also not immediately apparent to understand the challenges presented by being left-handed. Teaching a child to write with his or her left hand is not just the opposite from teaching how to write right-handed. A right-handed learner writes away from his or her body and pulls the pencil, while a left-handed learner must write toward her body in the process pushing the pen (Luff, 2014; Vazi et. al, 2013). It should be realized that schools risk reducing the 'selfesteem' of left-handed learners by not giving them the right support.

\section{Theoretical Framework}

The study was conceptualised within the Person-Environment Fit (PEF) theory (Edwards, 2008). This was necessary due to the incidence of task-related stress resulting from marginalising lefthanders. Writing with the left hand in a majority right-handed class was conceptualised as the biproduct of an imbalance between task-related environmental demands (Vazi et al, 2013) and interactional relations. It should be noted that the main premise of the PEF suggests that marginalisation does not arise from a person or their environment separately, but rather from the interactional relationship between a person and their environment (Edwards, 2008). As researchers, we therefore assume that marginalisation stress would be mostly reduced when there is a fit between the individual and a particular environment. It is observed that the PEF theory has influenced research in humanities and social sciences for many years (Vazi, et al 2013). Hence, the theory was found to be appropriate in investigating the issues on learners writing with the left hand in primary school classrooms.

\section{Methodology}

The study employed a descriptive survey design (Creswell, 2010). Systematic random sampling was used to select five primary schools in Masvingo urban. Purposive sampling was then used to select 40 participants comprising 20 teachers and 20 learners from the participating schools with the intention of gathering data on: experiences of left-handed learners in primary schools; strategies teachers use to teach young children who are left-handed; and perceptions on how teacher-learner interactions affect left-handed children's learning and development. Data were collected through focus group discussions, individual interviews and observations (Nieuwenhuis, 2016). Direct observations were used to assess learner's writing hand preference. Post observation reflective interviews were held after the observations in order to gain some insight 


\section{INTERNATIONAL JOURNAL OF ACADEMIC RESEARCH IN PROGRESSIVE EDUCATION AND}

DEVELOPMENT

Vol. 7, No. 4, 2018, E-ISSN: 2226-6348 @ 2018 HRMARS

on the perceptions of the left-handed learner's experiences; strategies of teaching left-handers; and how teacher-learner interactions affect left-handed children's learning and development.

A research diary was used to capture running field notes and writing reflective comments. The triangulation of data collection methods and data sources strengthened the reliability and validity of the research findings (Nieuwenhuis, 2016). Ethical considerations were realised through employing principles of anonymity, confidentiality, and participants' informed consent (De Vos et al, 2011). In this study, keeping the identity of individuals confidential offered privacy to participants. Obtaining permission and clearly communicating the purpose of the study before data collection lessened reservations some individuals might have had (Creswell, 2005). Tesch's open coding qualitative data analysis was used to analyse data. We used thick descriptive vignettes and direct quotes from the interviews and questionnaire. The strategy created mental images that brought to life the complexities of the variables inherent in primary school learners writing with the left hand in a majority right-handed learners' class (De Vos et al, 2011, Marshall \& Rossman 2011).

\section{Findings and Discussion}

Finding of this study were presented under three major themes namely: experiences of lefthanded learners; teaching strategies used to teach left-handers; and teacher-learner interactions and effect on left-handed children. Figure 1 below shows a summary of results and findings of the study.

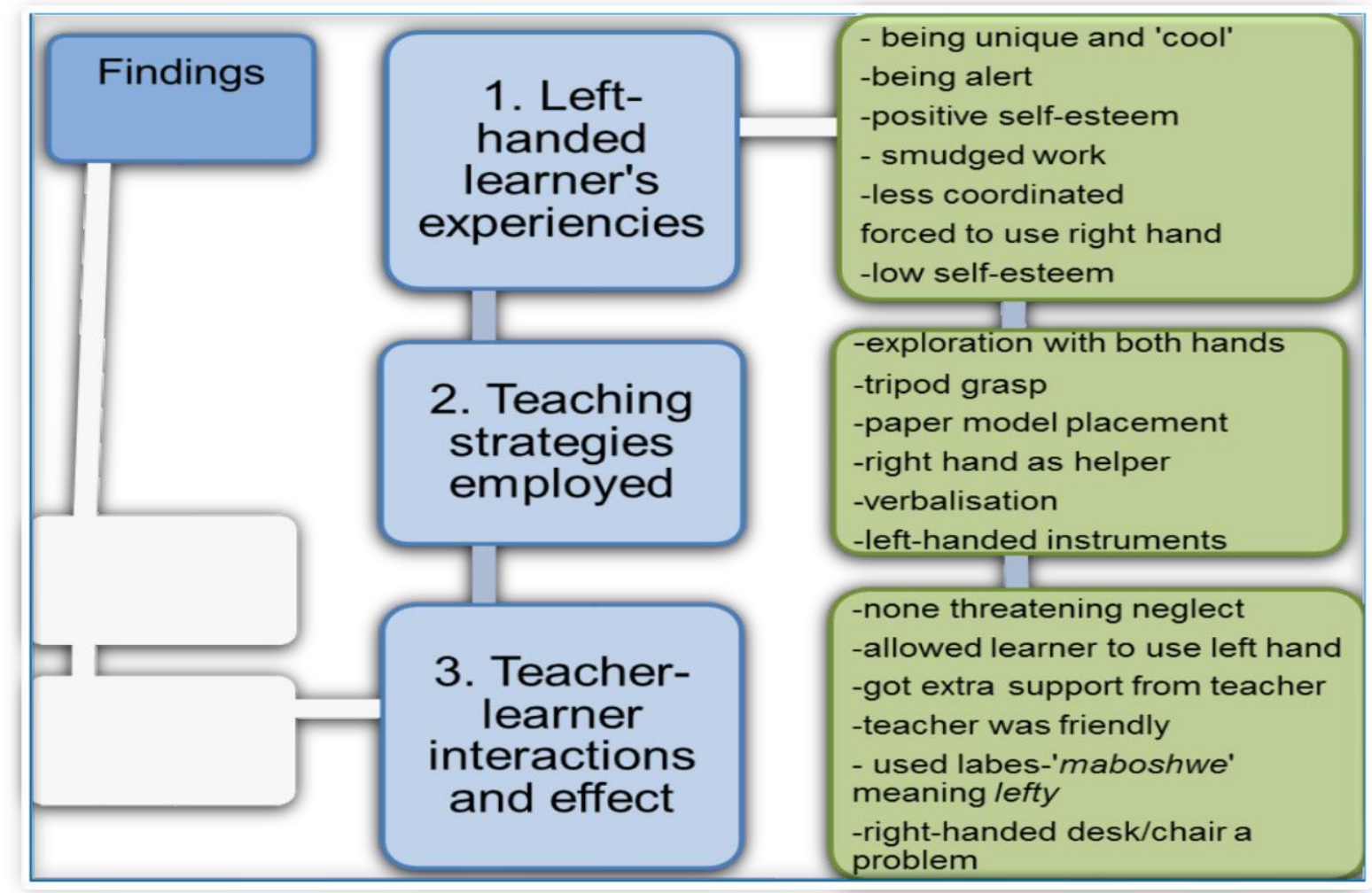

Figure 1: Summary of findings 
INTERNATIONAL JOURNAL OF ACADEMIC RESEARCH IN PROGRESSIVE EDUCATION AND

DEVELOPMENT

Vol. 7, No. 4, 2018, E-ISSN: $2226-6348 @ 2018$ HRMARS

\section{Experiences of left-handed learners}

The results of the study on children writing with the left hand in a majority right-handed class show both positive and negative attributes with findings more skewed to the negative. Some of the learners viewed writing with the left hand as being unique and 'cool'. The sentiment was explicit in the following articulated statements by left-handed learner participant.

"Our teacher treats me the same with as right handers, but I think I need more help and special attention. E I think being left handed has made me stronger, since I have to cope with right-handed friends. I am always thankful to my Grade one teacher who taught me how to hold a pencil."

As someone who writes with the left hand, I think that I have something additional. I have the willpower to adapt myself to a situation. I can learn things faster than my right-handed friends. Some people tell me that it's 'cool' to be left-handed. Now I am used to it and it has become normal to me.

Basing on one of the tenets of the Person-Environment Fit (PEF) theory that marginalisation does not arise from a person (Vazi et al, 2013) but the contextual environment. The captions above precisely show that being left-handed did not create disequilibrium within some the learners. Emphasising the uniqueness of being a left-hander, one of the learner participants stated:

I am surprised by some people who think that left-handers were taught something "wrong" in their formative years and first-time observers who say, 'Ah, you are lefthanded. Anyway, I am used to such comments. In class I always do my best to make righthanded peers feel like they are missing something.

Famous left-handed personalities include Leonardo Da Vinci, Michelangelo, Sir Isaac Newton, Mahatma Gandhi, Henry Ford and Barack Obama (Luff, 2014). However, some children are left feeling less coordinated or creative than their peers when faced with using classroom objects designed for people who are right-handed. Not all learners professed positive involvement and emotions in their experiences as left-handers. Some learners expressed undesirable experiences writing with the left hand in class. The following statements from three participants clearly reveal the situation.

I try my best to present clean work, but I find that my work would be smudged by my little finger on my left hand. If I use my left hand to write on the chalkboard, my writing becomes hard to read. I am learning to adapt to this right-handed world but still experience difficulties.

I see classrooms set up in a right-handed sense which makes it difficult for us the lefthanded people.

In sport I am always chosen last where handedness counted, for example in tennis, volleyball, netball and tunnel-ball. Left-handers are assumed to be clumsy, less co- 
INTERNATIONAL JOURNAL OF ACADEMIC RESEARCH IN PROGRESSIVE EDUCATION AND

DEVELOPMENT

Vol. 7, No. 4, 2018, E-ISSN: 2226-6348 @ 2018 HRMARS

ordinated and as good as right-handers. I think if teachers should see us kids as the same and we will not be mocked 'maboshwe' lefties.

These learners' expressions are a cry for positive recognition and equal treatment in our classrooms. Being left handed in a majority right-handed class is conceptualised as the bi-product of an imbalance between task-related challenges and environmental demands (Vazi et al, 2013). It should be noted that marginalisation does not arise from a person or their environment separately, but rather from the interactional relationship between a person and their environment. It shows that in some situations the classroom becomes an unfair environment for left-handed learners. In line with this observation, some participant expressed:

It is assumed you are naturally clumsy. It seems that right-handed adults are annoyed that left-handed children need assistance. There are no left-handed products in our class. I learned to adapt.

No help is given to left handers. In fact, some people make left handers use their right one. I am lucky our teacher allows me to use my left hand. We are happy people like you help us along. Thank You.

In school, there is no support for left-handed children. When I began to write, with my natural left-handed slant, most of my teachers insisted that I write with a right-handed slant. So, I tucked my elbow into my ribs and turned my paper. This made a person see my test answers.

Teachers must refresh their teaching theory in order to understand working with all children in inclusive classrooms. Explanations should be used to tell how all learners' existing ideas and practices can be connected usefully to enable learning (Mugweni, Musengi and Ganga, 2016). Using a teaching theory interrelated constructs, definitions and propositions on left-handed learners present a systematic view of teaching. Diversity should be welcomed in the $21^{\text {st }}$ century classrooms (Mugweni, et al, 2016).

\section{Teaching strategies used to teach left-handers}

The study results showed a number of strategies that teachers employ in their classrooms to work with left-handed learners. Mostly, the strategies teachers reported as useful were letting learners explore with both hands, hand dominance verbalisation, use of 'tripod' grasp, writing paper and model placement, right hand as 'helper hand' and use of ICT technologies.

\section{Exploration with both hands}

It should be noted that hand dominance fully develops between ages five and six. Toddlers and pre-schoolers who exhibit a left-handed preference at this age may still change to become fully right-handed at infant school level. Results show that children should not be forced or coerced into writing with the right hand. It was observed that children need to be allowed to explore using both hands. This will enable the child to develop a hand preference. Commenting on the matter, a teacher participant stated: 
Children need time to establish hand dominance. Here and there we guide them but not pushing you see. It's understood, they need to be guided like which hand to greet people with, to eat with and so on you see. This is the case with writing; we need to guide our left-handed learners in mastering and dominance.

An analysis of the statement shows that some teachers in the schools do create what I would call a writing support system around left-handed learners by scaffolding and facilitating during writing. The sentiments also imply right-handed dominance preference emanating from cultural practices by the teacher.

\section{Tripod grasp}

Results show that some of the teachers encouraged learners to pinch a pencil or pen with the index finger and thumb, resting the writing instrument on the middle finger - tripod grasp. This is the technique right-handed learners also apply. The grasp helps develop dynamic finger movements and proper wrist position. Children in contemporary classes are often not taught how to hold their pens and pencils correctly. Without proper teaching, right-handed learners find it easy to figure out a writing position but for the left-handed positioning is different. Hence, lefthanded learners may develop poor habits leading to bad writing behaviors as they get older with increasing writing demands. This was emphasized by a teacher who indicated:

The thing is a left-handed child is only allowed to write with the left hand but he or she is not taught how to write. Such a child may develop a unnecessarily painful, unproductive, slow and messy way of writing. This will in turn result in a lifelong hardship to the learner. It is important teachers and parents also to know how to teach left-handed children to write correctly.

It was espoused that left-handed learners should be taught to move their fingers up the pencil a little higher. This allows the learner to see what she is writing and less likely to have to hook their wrist in order to see properly. The correct grip reduces the smudge on the learner's writing.

\section{Writing paper and model placement}

Results show that right-handed learners tend to angle the right corner of their paper up when writing. Left-handed learners should adopt the same with the left side. The position places their writing arm in a natural position and allows them to write on paper lines properly as they move from left to right without having to excessively hook their wrist. These learners need to place their paper to the left of their body so that they can see what they are writing. When they finish writing across an entire line, their hand should either be slightly to the left of their midline or just in front of it.

Handwriting could be improved if left-handed learners were taught to write by angling the paper properly, relaxing their arms and positioning themselves on the right side of the desk. The posture allows the learner to move more naturally as she keeps her wrist straight (rather than 


\section{INTERNATIONAL JOURNAL OF ACADEMIC RESEARCH IN PROGRESSIVE EDUCATION AND DEVELOPMENT}

Vol. 7, No. 4, 2018, E-ISSN: 2226-6348 ๑ 2018 HRMARS

hooked), reduce smudging while writing, and see what she is writing (Holder, 2003). Figure 2 below shows an example of the correct paper positioning for learners who are left-handed.

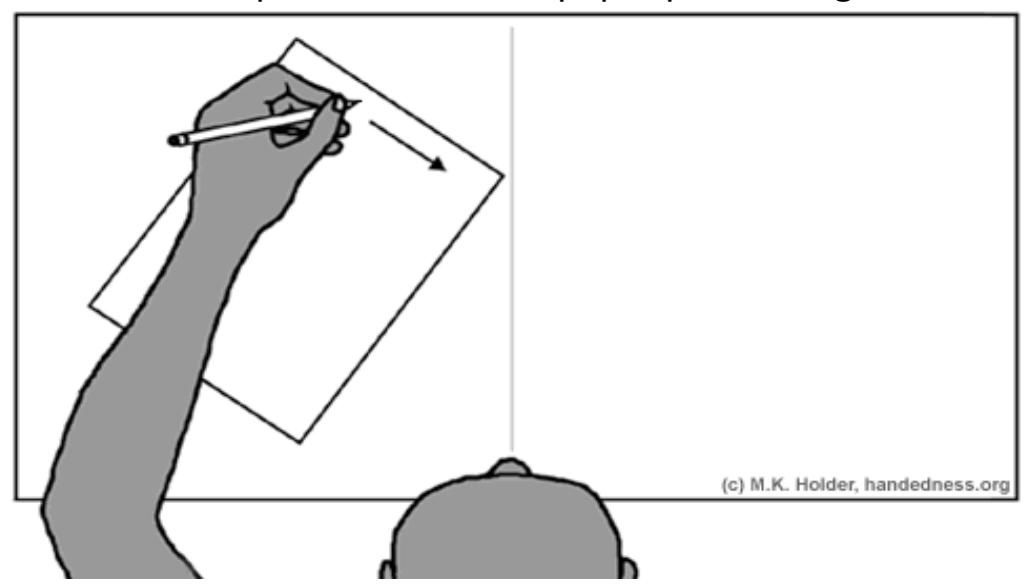

Figure 1: Positioning paper

Teachers had this to say:

I think left-handed children should be taught the position of the writing paper, arm, wrist, and the grip on the writing instrument. Yes, they need such training in our classrooms.

By supporting both left-handed and right-handed learners enhances inclusivity in regular classroom environments.

\section{Hook style of writing}

Without being taught how to position paper properly, left-handed learners tend to develop a hooked style of writing. The style poses letter formation and neatness challenges during executing written work.

Figure 3 below shows a visual of the hook style of writing by a left-handed learner.

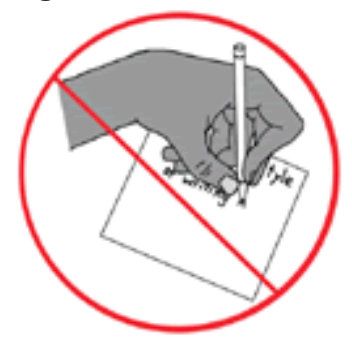

Figure 2: Hooked style of writing

Right hand as the "helper hand"

Teachers should always explicitly teach both right-handed and left-handed learners to steady their paper with their non-dominant hand. This should be a must for the left-handed children. The more consistently learners stabilize their paper, the less likely it is to move around causing less frustration while writing. This is because writing from left to right is not the natural direction for left-handers. A participant reported:

Both right-handed and left-handed learners need to be taught to steady their paper with the other hand that is not dominant. 
INTERNATIONAL JOURNAL OF ACADEMIC RESEARCH IN PROGRESSIVE EDUCATION AND

DEVELOPMENT

Vol. 7, No. 4, 2018, E-ISSN: $2226-6348$ ㄷ 2018 HRMARS

\section{Teacher-learner interactions and effect left-handed children Learner voices}

Regarding teacher-learner interactions and effect on left-handed learners, the study found that there were generally positive interactions between teachers and learners with limitations on resources compatible with left-handed learners (Holder, 2003). Commenting on teacher-learner interaction and its effect, learner participants stated:

After my teacher stopped trying to make me change, I am going through my school years under nonthreatening neglect.

My teacher always tells me that my work is too messy and smudgy! The right-handed desk-chairs are a huge problem! This kind of affects my marks.

Relating previous experiences and effects at a former school, a learner who is left handed narrated:

At my first primary school I was not given specific help, but at my new school I felt encouraged to keep writing with my left hand.

Some of my friends who are attending a different primary school to me used to be lefthanded, but were forced to change hands. Also, in primary school I was at one of the teachers I had selected left handers out as being "special", but not in a nice way. He was patronising than helpful, accusing us of being 'handicapped' in a way. Saying it was alright if our hand writing was messy and untidy, because we are left-handed.

\section{Teacher voices}

Teachers who were interacting with left-handed learners also had experiences to share. Two teachers who are left handed said:

As a left-handed teacher, I always check to see who is left-handed in my classes the first day. They get extra support as needed. I show them how to do some things the "lefty" way!

Being a left-handed teacher, I make it my mandate to try to help left handers generally and show them that it is not a handicap - I'm the one who write all the names on certificates for prizes. Learners can see that good writing is not just the preserve of the right handed. I am thinking of starting a left-handed writing club for Grade $6-7$ next year to boost the learners' confidence.

\section{Conclusions}

It was concluded that children who wrote with the left hand in a majority right-handed class show both positive and negative attributes. Findings were more skewed to the negative attributes of writing with the left hand in a majority right-handed class. 
INTERNATIONAL JOURNAL OF ACADEMIC RESEARCH IN PROGRESSIVE EDUCATION AND

DEVELOPMENT

Vol. 7, No. 4, 2018, E-ISSN: 2226-6348 ๑ 2018 HRMARS

Letting learners explore with both hands, hand dominance verbalisation, use of 'tripod' grasp, writing paper and model placement, right hand as 'helper hand' and use of ICT technologies were strategies teachers reported as useful when working with left-handed learners in primary school classrooms.

There were generally positive interactions between teachers and left-handed learners. More positive teacher-learner interaction was espoused by teachers who had the experience of being left-handed themselves. It was also concluded that schools had limited resources such as desks for use by left-handed learners.

Teachers who were interacting with left-handed learners had successful experiences that they shared with learners and other teachers.

In working with children on handwriting, it was found that teachers were often intimidated about how to teach left-handed learners to write. It should be understood, that there is no much difference in teaching right-handed and left-handed children to write. As suggested, there are a few hints to keep in mind, when teaching a left-handed child to write. The current teacher lack of understanding is leaving the "self-esteem and self-worth" of left-handed learners in regular classrooms at risk. In most cases children were left feeling "clumsy and awkward" in the classroom and on the sports field. The practice made children fail to reach their full creative potential. Other challenges faced by the learners were: over-tight grip, smudging, hook style, writing strain and mirror writing.

\section{Recommendations}

There is need for schools to provide appropriate resources for left-handed learners in order to reduce challenges of struggling with right-handed instruments and having cramped, illegible handwriting because teachers are unaware of their different needs. It was recommended that institutions of higher learning must staff develop teachers on how to help left-handed children in classrooms so that their self-efficacy and self-esteem is enhanced.

There is need to adopt use of the Left-Right Writing Guide in order to remind left-handed learners of the correct writing position and ease writing challenges. Specifically, there is need for primary school teachers to develop skills for them to be able to assist left-handed learners so that quality of the learners' handwriting is enhanced. There is need for creating a resource base for use by learners who are left-handed. Lastly, teachers, other learners and parents should collaborate in scaffolding left-handed learners to alleviate the challenges such learners face.

\section{Reference}

Boon, C. \& Hartog, D. N. (2011). Human Resource Management, person-environment fit, and trust. Trust and Human Resource Management, 109-121.

Creswell, J. W. (2010). Research Design: Qualitative, Quantitative, and Mixed Methods Approaches. (3rd Ed.) Thousand Oaks, California: Sage Publications

De Vos, A.S., Strydom, H., Fouché, C.B. \& Delport, C.S.L (Eds.). (2011). Research at the grassroots for social sciences and human science professions ( $4^{\text {th }}$ ed.). Hatfield, Pretoria: Van Schaik. 
INTERNATIONAL JOURNAL OF ACADEMIC RESEARCH IN PROGRESSIVE EDUCATION AND

DEVELOPMENT

Vol. 7, No. 4, 2018, E-ISSN: 2226-6348@ 2018 HRMARS

Edwards, J. R. (2008). Person-environment fit in organizations: An assessment of theoretical progress. The Academy of Management Annals, 2, 167-230.

Hancock, D.R. \& Algozzine, B. (2006). Doing case study research: A practical guide for beginning researchers. New York: Teachers College.

Holder, M.K. (2003). Teaching left-handers how to write. Handedness Research Institute papers. URL: handedness.org/action/leftwrite.html

Kristo-Brown, A. \& Guay, R. P. (2011). Person-environment fit. APA Handbook of Industrial and Organisational Psychology, 3, 3-50. Doi 10. 1037/2171-001.

Luff, P. (2014) Teachers must be trained to help left-handed children. Retrieved from. www.telegraph.co,uk.

Marshall, C. \& Rossman, G.B. (2011). Designing qualitative research (5 $5^{\text {th }}$ ed.). Thousand Oaks, CA: Sage Publications.

Mugweni, R. Ganga, E. \& Musengi, M. (2016). Theories, Principles and Perspectives of Teaching. In Okeke, CIO. Learn to Teach: A Handbook for Initial Teacher Education, PP 69-91. Cape Town: Oxford University Press.

Nieuwenhuis, J. (2016). Qualitative research designs and data-gathering techniques. In Maree, K. (2016). First steps in research ( $2^{\text {nd }}$ Ed.). Pretoria: Van Schaik Publishers.

Vazi, M.L.M., Ruiter, R.A.C., Borne, B., Martin, G., Dumont, K., Reddy, P.S. (2013). The relationship between wellbeing indicators and teacher psychological stress in Eastern Cape public schools in South Africa. South African Journal of Industrial Psychology, 39(1), Art. \#1042, 10pages. http://dx.doi.org/10.4102/sajip.v39i1.1042 